\title{
Endotoxic properties of free lipid A from Porphyromonas gingivalis
}

\author{
Ken-ichi Tanamoto, ${ }^{1}$ Satoko Azumi, ${ }^{1}$ Yuji Haishima, ${ }^{1}$ Hidefumi Kumada ${ }^{1,2}$ \\ and Toshio Umemoto ${ }^{2}$
}

1 Division of Microbiology, National Institute of Health Sciences, Setagayaku, Tokyo 158, Japan

2 Department of Oral Microbiology, Kanagawa Dental College, Yokosuka, Kanagawa 238, Japan
Author for correspondence: Ken-ichi Tanamoto. Tel: +8133700 1141. Fax: +8133707 6950.
e-mail: tanamoto@nihs.go.jp

Keywords : Porphyromonas gingivalis, lipopolysaccharide, lipid A, endotoxin

\section{INTRODUCTION}

A high incidence of Porphyromonas gingivalis has been found in periodontal abscesses (Winkelhoff et al., 1985) and the organism has been isolated from subgingival lesions and supragingival plaque in periodontal patients (Zambon et al., 1981); hence it is assumed to be one of the bacteria involved in the pathogenicity of periodontal diseases (Slots \& Genco, 1984; Slots \& Gibbons, 1978; Winkelhoff et al., 1993). The LPS from $P$. gingivalis expresses typical activities directly associated with the periodontal diseases of bone resorption, induction of various inflammatory cytokines (Hamada et al., 1990; lino \& Hopes, 1984; Nair et al., 1983; Sisney-Durrant \& Hopps, 1991; Takada et al., 1991), and induction of periodontal tissue alterations and destruction including attachment loss, collagen degradation and alveolar bone loss (Wilson, 1993). The LPS is, therefore, suspected to be one of the virulence factors of the bacterium, along

Abbreviations: FCS, foetal calf serum; TNF, tumour necrosis factor alpha. with others such as proteases, collagenase and adhesins (Birkedal-Hansen et al., 1988; Fujimura \& Nakamura, 1987; Slots \& Genco, 1984). Some investigators have reported that the LPS of $P$. gingivalis has a far more moderate endotoxic activity than the LPS from enterobacteria (Nair et al., 1983; Fujiwara et al., 1990; Takada et al., 1990). Since lipid A, the active centre of LPS, has not been isolated from LPS as the free form by conventional methods, all these data were obtained by using LPS, not lipid A, of structurally undefined preparations. Although the chemical composition of LPS has been analysed (Brondz et al., 1989; Johne et al., 1988) and its low endotoxicity has been hypothesized to depend on its unique fatty acid composition, its chemical properties, such as the structure of the backbone, substitution of the phosphate groups and distribution of fatty acids, have remained unknown. Therefore the reason for its low endotoxicity has not been discussed on a structural basis. Recently we succeeded in isolating the lipid A and determining its complete chemical structure (Kumada et al., 1995). The proposed chemical structure is shown in Fig. 1. The lipid A was characterized 


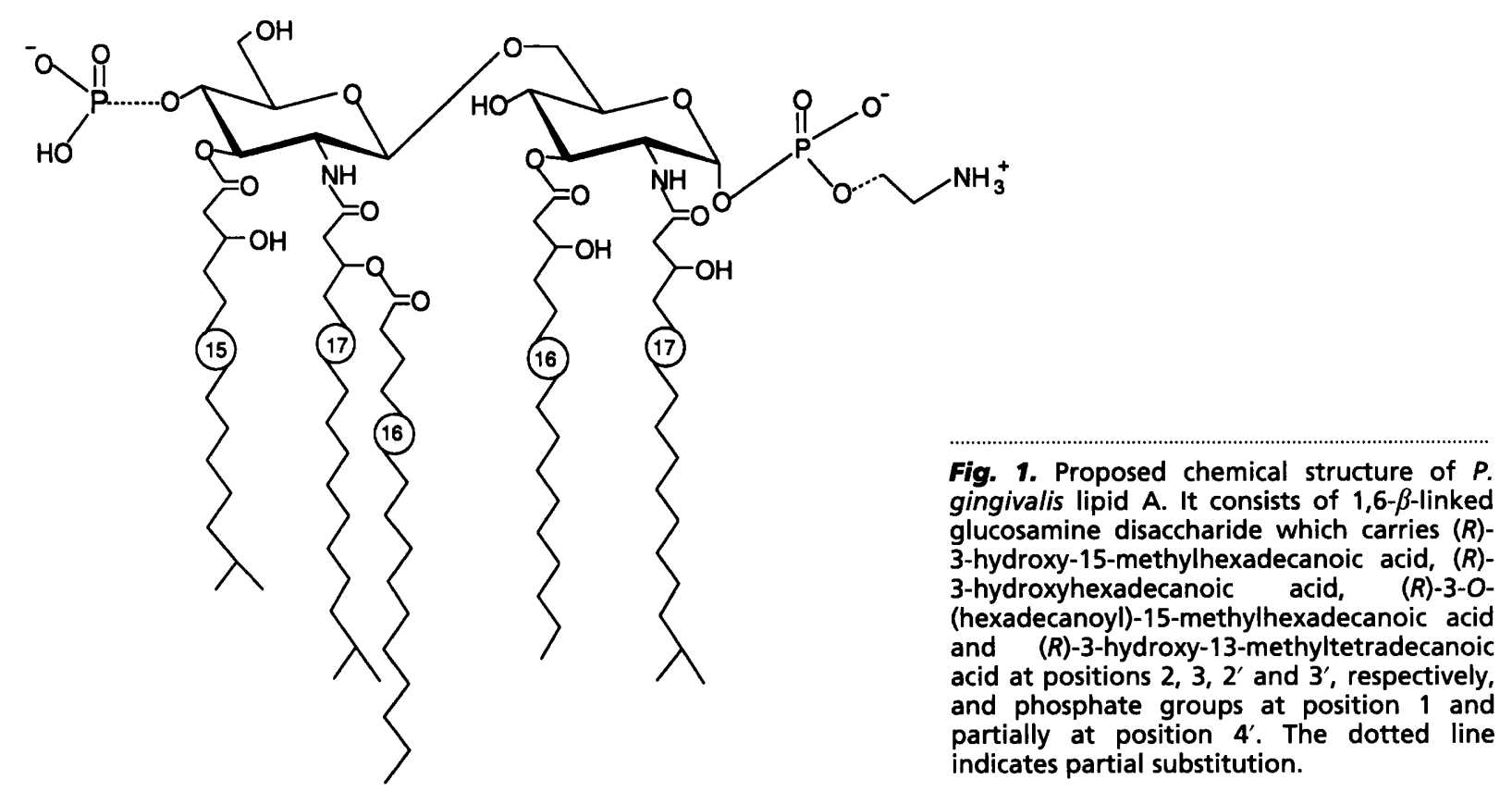

chemically by its unique components and substitution of branched fatty acids which are longer (15-17 carbon atoms) than found in enterobacterial LPS, which consists mainly of 3-hydroxytetradecanoic acid (Rietschel et al., 1984, 1988). The isolation of lipid A from $P$. gingivalis LPS and its structural determination makes it possible to study the relationship between structure and biological activity at the native lipid A level and to verify the biological data obtained with the LPS.

In the present investigation, the endotoxic activity of the chemically well-defined lipid A isolated from $P$. gingivalis LPS was studied together with that of the LPS itself and was compared with that of Salmonella minnesota LPS. The relationship between biological activity and chemical structure of the lipid A, which has a unique chemical structure, is discussed.

\section{METHODS}

Materials. $P$. gingivalis SU 63, isolated from a periodontal pocket, was used for the lipid A preparation. Recombinant TNF standards and rabbit polyclonal antisera against murine TNF were obtained from Asahi Kasei Kogyo. Escherichia coli type synthetic lipid A (506) was purchased from Daiichi Pharmaceutical. THP-1 and J774-1 cell lines were obtained from the Japanese Cancer Research Resources Bank (JCRB). Rabbit IgG was obtained from ZYMED laboratories. RPMI 1640 medium with glutamine and Iscove's modified Dulbecco's medium were from Gibco. Phorbol myristate acetate (PMA), 1,25-dihydroxy vitamin D3, and galactosamine were purchased from Sigma. Quantitative Limulus assay reagent (Endospecy) was obtained from Seikagaku Kogyo. Pyrogen-free water was a product of Hikari Seiyaku. Thioglycollate was purchased from Wako. LPS was extracted from $S$. minnesota by the aqueous phenol method (Westphal et al., 1952).

Preparation of $\boldsymbol{P}$. gingivalis lipid A. The method has been described by Kumada et al. (1995). LPS was extracted from acetone-dried cells with hot phenol/water (Westphal et al., 1952), digested with RNase A (Sigma), DNase I (Sigma) and proteinase K (Sigma) (Schifferle et al., 1989), then purified by repeated ultracentrifugation $\left(105000 \mathrm{~g}, 12 \mathrm{~h}, 15^{\circ} \mathrm{C}\right)$. The LPS was sonicated for $5 \mathrm{~min}$ in a mixture of phenol/chloroform/ light petroleum (b.p. $30-60^{\circ} \mathrm{C}$ ) (PCP) $(2: 5: 8$, by vol.) and after centrifugation, the sediment was further washed twice with the PCP mixture and three times with acetone, then lyophilized. The purified LPS (yield; $4 \cdot 2 \%$ from dried cells) contained $39 \cdot 2 \%$ total carbohydrate, $20.1 \%$ total lipid, $19.7 \%$ amino sugar, $2.5 \%$ total phosphate and $2.2 \%$ protein. Lipid A was isolated and purified according to the methods described previously by Qureshi et al. (1985) and Qureshi \& Takayama (1982), with some modification. The lipid A was liberated from the LPS $(1.25 \mathrm{~g})$ by heating at $100{ }^{\circ} \mathrm{C}$ in $1 \%(\mathrm{w} / \mathrm{v})$ acetic acid for $90 \mathrm{~min}$. Free lipid $\mathrm{A}$ was obtained from the hydrolysate by extracting with an equal volume of chloroform/ methanol $(1: 1, v / v)$. The organic phase was washed three times with distilled water and evaporated under reduced pressure, then lyophilized to yield crude lipid A (434 mg). The sample was dissolved in PCP to eliminate possible contaminants. After evaporation, the remaining phenol phase was saturated with distilled water. Four volumes of cold acetone was added to the phenol phase, and the precipitate was collected by centrifugation followed by washing twice with acetone and twice with ethanol. The lipid A was dissolved in chloroform/methanol $(3: 1, \mathrm{v} / \mathrm{v} ; 2 \mathrm{ml})$, passed through a small column $(1 \times 5 \mathrm{~cm})$ of Dowex $50\left(\mathrm{H}^{+}\right)$, and purified by gel permeation chromatography on Sephadex LH-20 (Pharmacia) in a column $(2.5 \times 100 \mathrm{~cm})$ using chloroform/methanol $(3: 1$, $\mathrm{v} / \mathrm{v}$ ) as the eluent (flow rate $24 \mathrm{ml} \mathrm{h}^{-1}$ ). The purified lipid A contained about $1.8 \%$ protein as estimated by amino acid analysis, and no sugar according to the results of gas-liquid chromatography and gas-liquid chromatography/mass spectrometry, indicating no contamination by LPS. The proposed chemical structure is shown in Fig. 1. Since the lipid A was insoluble in water because of its extreme hydrophobicity, it was solubilized by converting it into a triethylamine form as follows. The lipid A was suspended in ice-cold $0 \cdot 1 \mathrm{M} \mathrm{HCl}$ at a concentration of $2 \mathrm{mg} \mathrm{ml}^{-1}$, sonicated and centrifuged in the 
cold. It was washed twice with distilled water and solubilized in water by adding $0.2 \mu \mathrm{l}$ triethylamine $(\mathrm{mg} \text { lipid } \mathrm{A})^{-1}$ at $0^{\circ} \mathrm{C}$. The excess triethylamine in the solution was immediately removed by blowing $\mathrm{N}_{2}$ to obtain a neutral $\mathrm{pH}$ (Tanamoto et al., 1984b). The solubilized lipid A solution was used for biological assay.

Mice. Female BALB/c and $\mathrm{C} 3 \mathrm{H} / \mathrm{HeN}$ mice $(6-10$ weeks old; Nihon SLC) were used for the assay of splenic mitogenicity and the induction of TNF release from peritoneal macrophages, respectively. For the lethality test we used female C57BL/6 mice, at least 10 weeks old, from Nihon SLC.

Mitogenicity assay. The method was originally described by Tanamoto (1984a). Spleen cells isolated from mice were mashed gently, passed through a wire grid and suspended in serum-free Iscove's modified Dulbecco's medium containing L-glutamine and HEPES buffer supplemented with penicillin $\left(100\right.$ units ml $\left.^{-1}\right)$ and streptomycin $\left(100 \mu \mathrm{g} \mathrm{ml}^{-1}\right)$. The cells were washed three times with the medium and adjusted to $4 \times 10^{6}$ cells (ml Iscove's medium) ${ }^{-1}$. After the addition of various amounts of test samples they were cultured on 96-well microplates (Corning), containing $200 \mu \mathrm{l}$ cell suspension in each well, for $48 \mathrm{~h}$ at $37^{\circ} \mathrm{C}$ in a humidified environment in the presence of $5 \%(\mathrm{v} / \mathrm{v}) \mathrm{CO}_{2} \cdot\left[{ }^{3} \mathrm{H}\right]$ Thymidine $[0 \cdot 2 \mu \mathrm{Ci}(7 \cdot 4 \mathrm{kBq})$ per culture; Amersham] was added, and they were incubated for a further $24 \mathrm{~h}$. The cells were harvested on glass fibre filters, and the radioactivity incorporated into the cells was measured in toluene-based scintillation fluid $(5 \mathrm{ml})$ by a scintillation counter. Data are expressed as mean c.p.m. of triplicate determinations.

Induction of TNF and NO release from mouse peritoneal macrophages. Mouse peritoneal macrophages were obtained by washing the peritoneal cavity with $5 \mathrm{ml}$ Iscove's medium (Tanamoto, 1994b). For the NO induction test, macrophages from mice which had been injected intraperitoneally with $2 \mathrm{ml}$ sterile $2.9 \%(\mathrm{w} / \mathrm{v})$ thioglycollate broth $4 \mathrm{~d}$ earlier were used. Aliquots of a cell suspension (1 ml) adjusted to $2 \times 10^{6}$ cells (ml Iscove's medium $)^{-1}$ were cultured in 24-well Costar plates at $37^{\circ} \mathrm{C}$ with $5 \%(\mathrm{v} / \mathrm{v}) \mathrm{CO}_{2}$ for $3 \mathrm{~h}$, and the macrophages were allowed to adhere to the plate. After the cells had been washed three times with Dulbecco's PBS $(-$ ) (Nissui Pharmaceutical), $1 \mathrm{ml}$ Iscove's medium was added to each well and the cells were incubated with the test sample for $6 \mathrm{~h}$ for TNF induction and $72 \mathrm{~h}$ for $\mathrm{NO}$ induction. The supernatant of each culture was transferred to a plastic tube, the cells were centrifuged at 2000 r.p.m. and the supernatant was stored at $-80^{\circ} \mathrm{C}$ until use for the determination of TNF and NO.

Induction of TNF and NO release from the J774-1 macrophage cell line. J774-1 cells were grown in RPMI 1640 medium supplemented with $10 \%(\mathrm{v} / \mathrm{v})$ heat-inactivated foetal calf serum (FCS), $50 \mu \mathrm{M}$ 2-mercaptoethanol, $5 \mathrm{mM}$ HEPES, penicillin $\left(100\right.$ units $\left.\mathrm{ml}^{-1}\right)$ and streptomycin $\left(100 \mu \mathrm{g} \mathrm{ml}^{-1}\right)$ in a $5 \% \mathrm{CO}_{2}$ atmosphere at $37^{\circ} \mathrm{C}$. The cells were harvested by scraping with a cell scraper (Costar) and suspended in fresh medium. The cells $\left(1 \times 10^{6}\right.$ cells ml $^{-1}$ per well of 24 -well dishes) were allowed to adhere to the plastic for $3 \mathrm{~h}$ at $37^{\circ} \mathrm{C}$, washed twice with medium and incubated with the stimulant for an additional $4 \mathrm{~h}$ for TNF induction and $72 \mathrm{~h}$ for NO induction. The supernatant of each culture was transferred to a plastic tube, the cells were centrifuged at 2000 r.p.m., and the supernatant was stored at $-80^{\circ} \mathrm{C}$ until used to determine TNF and NO.

Induction of TNF release from THP-1 cells. THP-1 cells were grown in RPMI 1640 medium supplemented with $10 \%$ heatinactivated FCS, $50 \mu \mathrm{M}$ 2-mercaptoethanol, $5 \mathrm{mM}$ HEPES, penicillin $\left(100\right.$ units $\left.\mathrm{ml}^{-1}\right)$ and streptomycin $\left(100 \mu \mathrm{g} \mathrm{ml}^{-1}\right)$ in a $5 \% \mathrm{CO}_{2}$ atmosphere at $37^{\circ} \mathrm{C}$. The cells $\left(2 \times 10^{5}\right.$ cells ml ${ }^{-1}$ per well of 24-well dishes) were prepared for the experiments by adding $100 \mathrm{ng} \mathrm{PMA} \mathrm{ml}^{-1}$, which had been stored as a $1 \mathrm{mg} \mathrm{ml}^{-1}$ solution in dimethyl sulfoxide and diluted with the medium immediately prior to use (Golenbock et al., 1991), and $0.1 \mu \mathrm{M} 1,25$-dihydroxy vitamin $\mathrm{D} 3$, to induce adherence to plastic and expression of CD14 (Kitchens et al., 1992), to cell suspensions in RPMI 1640 medium containing $10 \%$ FCS. The cell suspensions were allowed to differentiate and adhere to plastic for $72 \mathrm{~h}$ at $37^{\circ} \mathrm{C}$. After washing twice with medium, the cells were incubated for an additional $24 \mathrm{~h}$ with the stimulant. The supernatant of each culture was transferred to a plastic tube, the cells were centrifuged at 2000 r.p.m., and the supernatant was stored at $-80^{\circ} \mathrm{C}$ until used to determine TNF.

TNF assay. The TNF produced was measured by cytotoxicity assay against L929 murine fibroblast cells. L929 cells were grown in tissue culture flasks of RPMI 1640 medium supplemented with $10 \% \mathrm{FCS}, 50 \mu \mathrm{M}$ 2-mercaptoethanol, $5 \mathrm{mM}$ HEPES, penicillin (100 units $\left.\mathrm{ml}^{-1}\right)$ and streptomycin $\left(100 \mu \mathrm{g} \mathrm{ml}^{-1}\right)$. Cells were detached with trypsin, washed, resuspended in medium at $4 \times 10^{5} \mathrm{cells} \mathrm{ml}^{-1}$, and $100 \mu \mathrm{l}$ aliquots were plated in 96-well flat-bottomed plates (Corning). After incubation for $3-5 \mathrm{~h}$ at $37^{\circ} \mathrm{C}$ in $5 \% \mathrm{CO}_{2}, 50 \mu \mathrm{l}$ actinomycin D $\left(4 \mu \mathrm{g} \mathrm{ml}^{-1}\right)$ in RPMI medium was added to each well, and $50 \mu$ test sample was then added to the wells (final volume $200 \mu \mathrm{l}$ per well). After $20 \mathrm{~h}$ incubation, the cells were washed twice with Hanks' Balanced Salt Solution. The cells were then stained with crystal violet, and the cytotoxicity was measured by reading the $A_{550}$ of the extract with ethanol solution. The results were expressed as the means of triplicate determinations.

NO assay. NO produced in the supernatant was measured as a stable form of nitrite $\left(\mathrm{NO}_{2}^{-}\right.$) by using Griess reagent (Green et al., 1982). Briefly, $100 \mu \mathrm{l}$ test sample was mixed with the same volume of Griess reagent $[0.1 \% \quad(\mathrm{w} / \mathrm{v}) \quad \mathrm{N}-(1-$ naphthyl)ethylenediamine dihydrochloride in $\mathrm{H}_{2} \mathrm{O} / 1 \%$ (w/v) sulfanilamide in $\left.5 \%(\mathrm{v} / \mathrm{v}) \mathrm{H}_{3} \mathrm{PO}_{4} ; 1: 1(\mathrm{v} / \mathrm{v})\right]$ in a 96-well plate, and the $A_{550}$ was read with a microplate reader (Molecular Devices).

Lethal toxicity test. The lethality test was performed according to the method described by Galanos et al. (1979). Test samples in $0.1 \mathrm{ml}$ pyrogen-free water were injected intravenously immediately after intraperitoneal administration of $12 \mathrm{mg}$ D-galactosamine in $0.5 \mathrm{ml}$ pyrogen-free PBS.

Limulus amoebocyte gelation assay. Activation of the proclotting enzyme of the horseshoe crab, Limulus polyphemus, was estimated colorimetrically by measuring the absorbance of $p$-nitroaniline released from a synthetic substrate in a quantitative assay (Endospecy). The assay was performed in 96-well Costar flat plates at $37^{\circ} \mathrm{C}$ for $30 \mathrm{~min}$, and the chromogen was measured at $405 \mathrm{~nm}$ using a microplate reader. Pyrogen-free water was used to dilute the test samples.

\section{RESULTS}

\section{Mitogenicity of $\boldsymbol{P}$. gingivalis lipid A}

The mitogenic activities of $P$. gingivalis LPS and lipid A were tested on murine splenic cells of LPS-responsive BALB/c mice. As shown in Fig. 2, P. gingivalis LPS and lipid A exhibited comparable mitogenicity. The activity was, however, about 100 times less than that of $S$. minnesota LPS when the minimum stimulation dose was compared. 


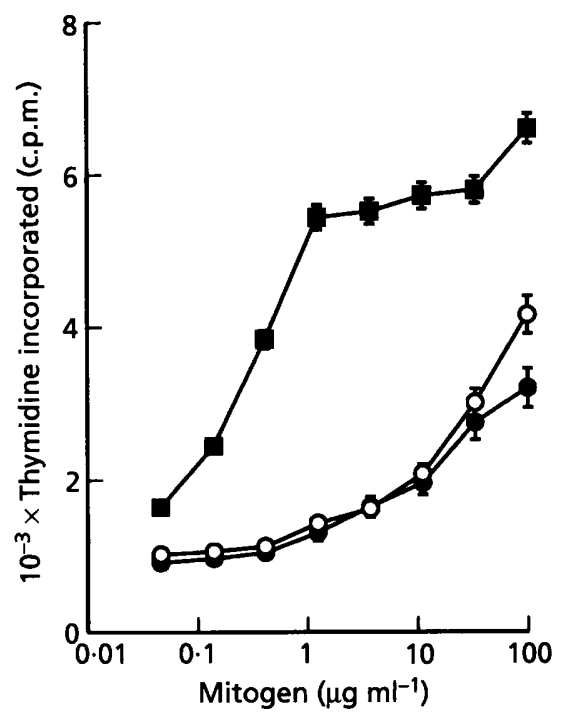

Fig. 2. Mitogenic responses of murine spleen cells to $P$. gingivalis LPS and lipid A. Spleen cells from BALB/c mice were suspended in serum-free Iscove's medium at $4 \times 10^{6}$ cells ml-1, $200 \mu \mathrm{l}$ aliquots were plated in 96-well tissue culture dishes, and reciprocally diluted mitogen in $10 \mu \mathrm{l}$ water was added. After culturing the cells for $48 \mathrm{~h},\left[{ }^{3} \mathrm{H}\right]$ thymidine $[0.2 \mu \mathrm{Ci}(7.4 \mathrm{kBq})$ per well] was added. After additional culture for $24 \mathrm{~h}$, the cells were harvested and the incorporated radioactivity was measured. The results are expressed as mean c.p.m. in triplicate experiments \pm SD. The background c.p.m. with no lipid $A$ was $845 \pm 40$ (mean \pm SD). $\square, S$. minnesota LPS; $O$, $P$. gingivalis LPS; $O, P$. gingivalis lipid $A$.

\section{Induction of TNF and NO release by $P$. gingivalis lipid A from mouse peritoneal macrophages}

TNF and NO released into the medium from mouse peritoneal macrophages after stimulation with $P$. gingivalis LPS and lipid A were measured. As shown in Fig. 3, the cells from $\mathrm{C} 3 \mathrm{H} / \mathrm{HeN}$ mice started to secrete TNF at a concentration of $10 \mathrm{ng} \mathrm{ml}^{-1}$ when stimulated with lipid A. The induction of TNF release from macrophages by lipid A increased dose-dependently, and maximum TNF production $\left(22 \mathrm{ng} \mathrm{m}^{-1}\right)$ was observed at the highest concentration tested, $10 \mu \mathrm{g} \mathrm{ml}^{-1}$. Similar, but slightly higher, activity was induced by LPS of the same bacterium. However, the activity of these preparations was much lower, especially with regard to the minimum dose needed to stimulate TNF production, than that of $S$. minnesota LPS, which stimulated the cells at a concentration of $0 \cdot 1 \mathrm{ng} \mathrm{ml}^{-1}$ and induced the maximum TNF production, $64 \mathrm{ng} \mathrm{ml}^{-1}$, at a concentration of $10 \mu \mathrm{g} \mathrm{ml}^{-1}$. In order to determine whether the cytotoxic activity against L929 cells was due to TNF, supernatants from a macrophage culture were incubated for $12 \mathrm{~h}$ with polyclonal rabbit antiserum to TNF, with nonspecific IgG used as the control. The polyclonal antibody to TNF completely abolished the cytotoxicity of the supernatants in all the samples tested. Although the resident peritoneal macrophages failed to produce a significant amount of NO, thioglycollate-induced
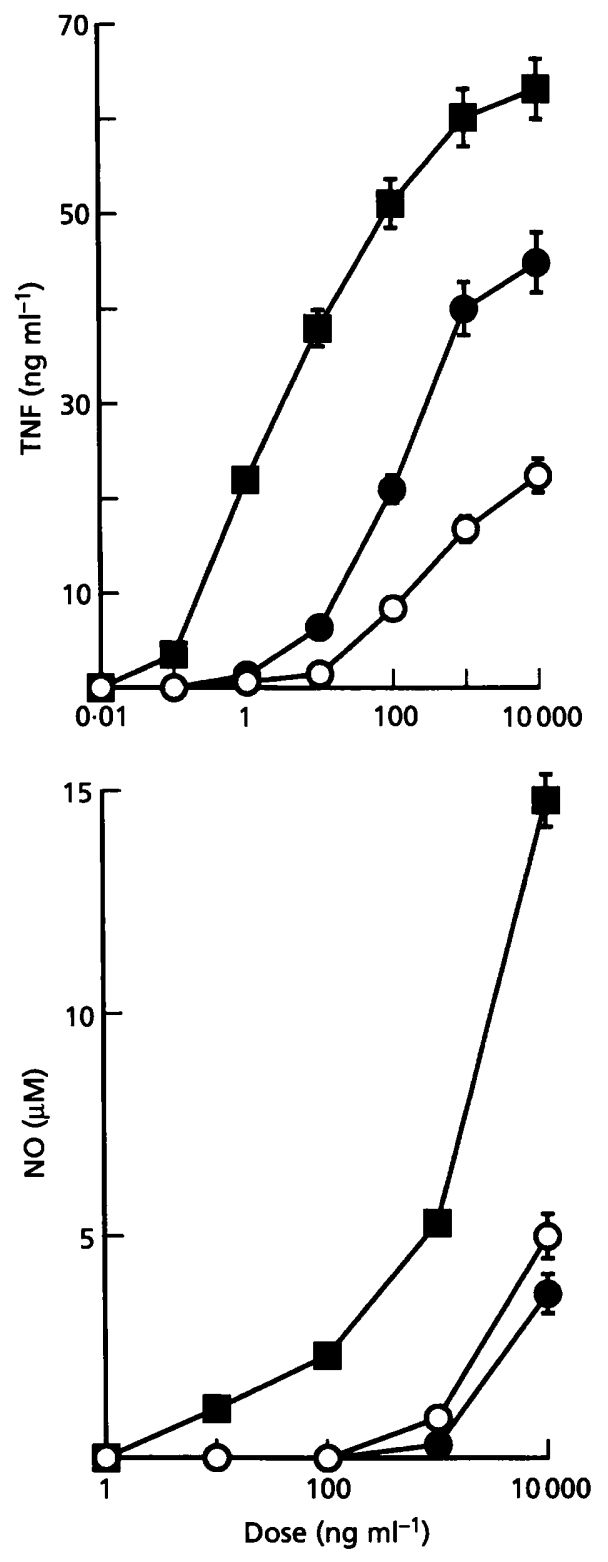

Fig. 3. Induction of TNF and NO release from murine peritoneal macrophages by $P$. gingivalis LPS and lipid A. Resident and thioglycollate-induced peritoneal macrophages from BALB/C mice were used for TNF- and NO-inducing assays, respectively. Macrophages, $2 \times 10^{6} \mathrm{ml}^{-1}$, were incubated in serum-free Iscove's medium with various concentrations of LPS or lipid A. After 6 and $72 \mathrm{~h}$ incubation at $37^{\circ} \mathrm{C}$, the supernatants were examined for TNF and NO, respectively. The results are expressed as means \pm SD of triplicate experiments. $\square, S$. minnesota LPS; O. P. gingivalis LPS; O, P. gingivalis lipid A.

macrophages responded to stimulation by LPS and produced NO. As shown in Fig. 3, however, the cells required a much higher concentration of LPS to induce NO than TNF, and they started to secrete NO at $10 \mathrm{ng}$ $S$. minnesota LPS $\mathrm{ml}^{-1}$. The ability of $P$. gingivalis lipid A to induce NO was about 100 times lower than that of the control LPS, and the production of NO was first observed at a concentration of $1 \mu \mathrm{g} \mathrm{m}^{-1}$. This activity of 

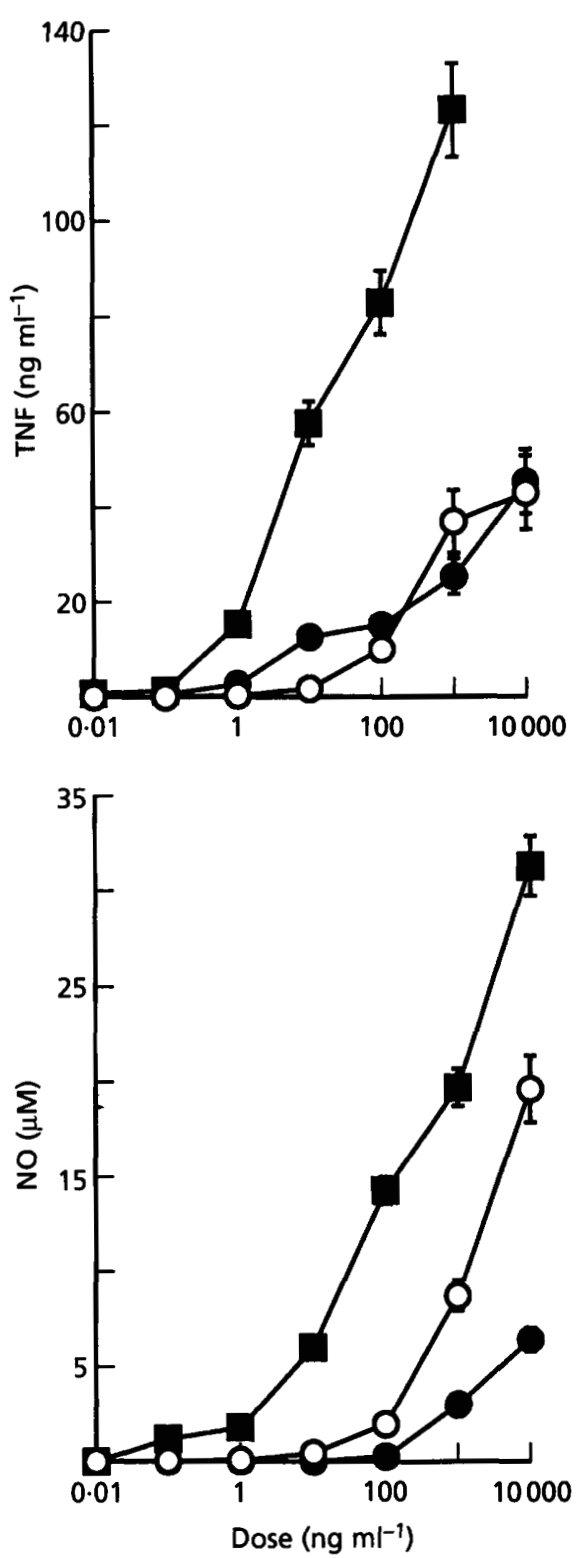

Fig. 4. Induction of TNF release from J774- 1 cells by $P$. gingivalis LPS and lipid A. J774-1 cells $\left(1 \times 10^{6}\right.$ cells $\mathrm{I}^{-1}$ per well of 24-well dishes) were incubated in RPMI 1640 medium supplemented with $10 \%(\mathrm{v} / \mathrm{v})$ FCS with the stimulant. After 4 and $72 \mathrm{~h}$ incubation at $37^{\circ} \mathrm{C}$, the supernatants were examined for TNF and NO, respectively. The results are expressed as means \pm SD of triplicate experiments. $\square$, S. minnesota LPS; O, P. gingivalis LPS; O, P. gingivalis lipid A.

$P$. gingivalis LPS was significantly lower than that of the lipid A, in contrast to TNF induction.

\section{Induction of TNF and NO release from J774-1 cells by $P$. gingivalis lipid A}

The ability of $P$. gingivalis lipid A as well as LPS to induce TNF and NO release from mouse macrophagelike J774-1 cells was compared with that of $S$. minnesota LPS used as a control. The cells are very sensitive to

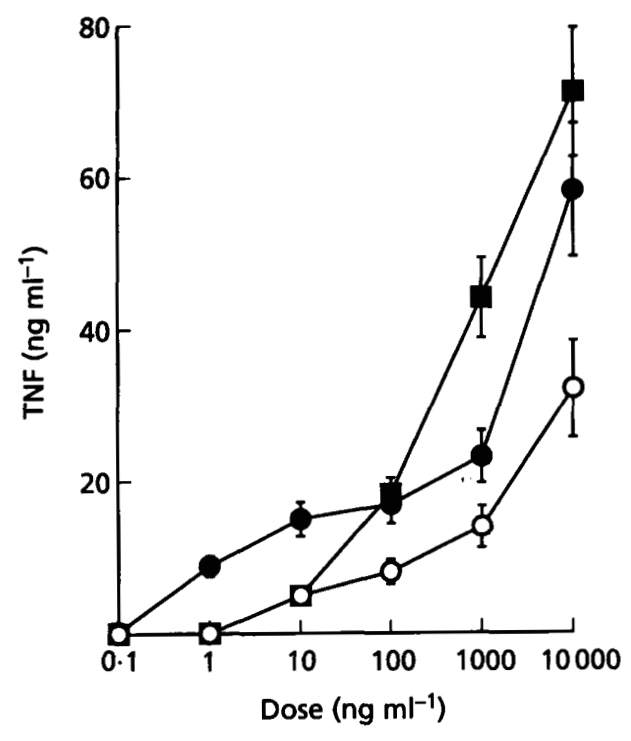

Fig. 5. Induction of TNF release from human THP-1 cells by $P$. gingivalis LPS and lipid A. Human THP-1 cells $\left(2 \times 10^{5}{\text { cells } \mathrm{ml}^{-1}}^{-1}\right.$ per well) were incubated with $100 \mathrm{ng}^{\text {PMA ml}} \mathrm{m}^{-1}$ and $0.1 \mu \mathrm{M}$ 1,25-dihydroxy vitamin D3 for $3 \mathrm{~d}$ in RPMI medium containing $10 \%(\mathrm{v} / \mathrm{v}) \mathrm{FCS}$ at $37^{\circ} \mathrm{C}$. After an additional $24 \mathrm{~h}$ incubation with $10 \mu \mathrm{l}$ test sample, the supernatants were assayed for TNF. Values represent the mean concentration of TNF \pm SD for triplicate experiments. $\square$, S. minnesota LPS; O, P. gingivalis LPS; O, P. gingivalis lipid A.

stimulation by the control LPS, and significant production of both TNF $\left(1.3 \mathrm{ng} \mathrm{ml}^{-1}\right)$ and NO $(1.2 \mu \mathrm{M})$ was observed at a concentration of $0 \cdot 1 \mathrm{ng} \mathrm{ml}^{-1}$ (Fig. 4). $P$. gingivalis lipid A started to induce secretion of both TNF and NO from J774-1 cells at a concentration of $10 \mathrm{ng} \mathrm{ml}^{-1}$, showing that the activity is about 100 times lower than that of the control LPS. The activity of $P$. gingivalis LPS was a little higher than that of the lipid A in the case of TNF induction, but was about 10 times lower in the case of NO induction, giving results similar to those obtained with mouse peritoneal macrophages as described above.

\section{Induction of TNF release from THP-1 cells by P. gingivalis lipid A}

It is suggested that human cells respond to LPS in a different way from murine cells, as was seen in the response to the lipid A precursor. To determine the ability of $P$. gingivalis lipid A to activate human cells, the human monocyte-macrophage cell line THP-1 was examined for TNF production in response to P. gingivalis lipid A. As shown in Fig. 5, the cells were stimulated with $S$. minnesota LPS at a concentration of $10 \mathrm{ng} \mathrm{ml}^{-1}$ and produced $4.9 \mathrm{ng} \mathrm{TNF} l^{-1}$. They unexpectedly produced a comparable amount of TNF in the medium after stimulation with the same concentration of $P$. gingivalis lipid A. More pronounced activity was expressed by $P$. gingivalis LPS, which induced $8.8 \mathrm{ng}$ TNF $\mathrm{ml}^{-1}$ even at a concentration of $1 \mathrm{ng} \mathrm{ml}^{-1}$. 
Table 1. Lethal toxicity of $P$. gingivalis LPS and lipid A for galactosamine-sensitized C57BL/6 mice

Test samples in $0 \cdot 1 \mathrm{ml}$ pyrogen-free water were injected either intraperitoneally (i.p.) or intravenously (i.v.) immediately after intraperitoneal administration of $12 \mathrm{mg}$ D-galactosamine in $0.5 \mathrm{ml}$ pyrogen-free PBS.

\begin{tabular}{|c|c|c|c|c|c|c|}
\hline \multirow[t]{2}{*}{ Sample } & \multirow[t]{2}{*}{ Route } & \multicolumn{5}{|c|}{$\begin{array}{l}\text { No. of dead/total no. tested } \\
\text { at the following dose } \\
\text { ( } \mu \text { g per mouse) }\end{array}$} \\
\hline & & 0.001 & 0.01 & 0.1 & 0.3 & 1 \\
\hline S. minnesota LPS & i.p. & $3 / 8$ & $6 / 6$ & & & \\
\hline $\begin{array}{l}\text { E. coli synthetic } \\
\text { lipid A (506) }\end{array}$ & i.v. & $3 / 9$ & $6 / 6$ & & & \\
\hline \multirow{2}{*}{ P. gingivalis LPS } & i.p. & & & $0 / 3$ & & $0 / 6$ \\
\hline & i.v. & & & $0 / 6$ & & $3 / 3$ \\
\hline P. gingivalis lipid A & i.v. & & & $0 / 6$ & $3 / 6$ & $3 / 3$ \\
\hline
\end{tabular}

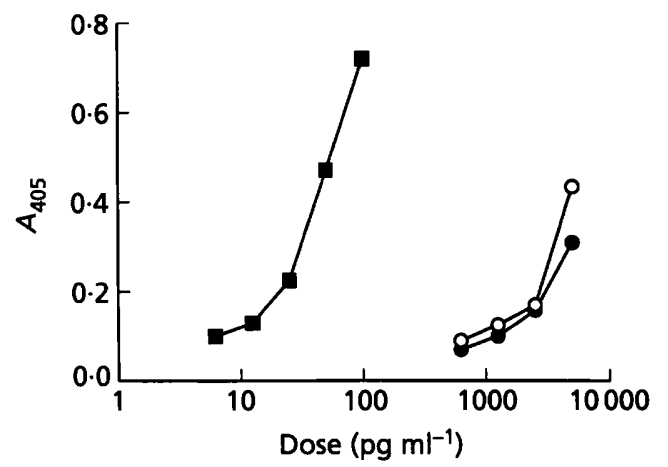

Fig. 6. Limulus gelation activity of $P$. gingivalis LPS and lipid A. Limulus amoebocyte lysate was incubated with test samples for $30 \mathrm{~min}$, and the chromogen released was measured. $\square, S$. minnesota LPS;,$P$. gingivalis LPS; $O, P$. gingivalis lipid A.

\section{Lethal toxicity of $\boldsymbol{P}$. gingivalis lipid A}

The lethal toxicity of the samples was tested using galactosamine-sensitized mice. The results are shown in Table 1 . In this system, S. minnesota LPS exhibited almost $100 \%$ lethality at $10 \mathrm{ng}$ per mouse, and moderate lethality was observed even at $1 \mathrm{ng}$ per mouse. On the other hand, the lethality of $P$. gingivalis LPS was first observed at $1 \mu \mathrm{g}$ per mouse when it was injected intravenously, and no lethality was observed at $0 \cdot 1 \mu \mathrm{g}$ per mouse, or at $1 \mu \mathrm{g}$ per mouse injected intraperitoneally. The lipid A of $P$. gingivalis exhibited $100 \%$ lethality at $1 \mu \mathrm{g}$ per mouse, and no lethality was seen at $0 \cdot 1 \mu \mathrm{g}$ per mouse.

\section{Chromogenic Limulus amoebocyte lysate test of P. gingivalis lipid A}

S. minnesota LPS activated the cascade of the clotting system of the horseshoe crab at a concentration of several $\mathrm{pg} \mathrm{ml}^{-1}$, and linear dose-dependency was obtained up to $100 \mathrm{pg} \mathrm{ml}^{-1}$. In contrast, both LPS and lipid A from $P$. gingivalis showed negligible activity. The same chromogenicity, $A_{405} 0 \cdot 3$, was obtained at $30 \mathrm{pg} S$. minnesota LPS ml ${ }^{-1}, 3.5 \mathrm{ng} P$. gingivalis lipid $\mathrm{A} \mathrm{ml}^{-1}$ and $5 \mathrm{ng} P$. gingivalis LPS $\mathrm{ml}^{-1}$ (Fig. 6).

\section{DISCUSSION}

We examined the biological activity of the free form of lipid A from $P$. gingivalis, which was recently isolated and chemically characterized (Kumada et al., 1995). Although some differences were observed between the lipid A and its original LPS in activating mouse peritoneal macrophages and J774-1 cells to induce TNF and NO, the endotoxic activity of the two preparations was found to be almost identical, and was generally much more moderate than that induced by the LPS of $S$. minnesota, which was used as a control. In most of the systems used in this study to measure endotoxic activity, the lipid A exhibited activity at least 100 -fold less than the LPS of $S$. minnesota. The lipid A used in the present study contained a small amount $(1 \cdot 8 \%)$ of protein. The possibility of its participation in the activity, however, seems to be small considering that the protein content is low and that it is unlikely that the residual protein retains its intact form and function after proteinase treatment. Furthermore, the activity of the lipid A relative to that of $S$. minnesota LPS in B cell mitogenicity and activation of macrophage and other cells, which are possibly induced by the contaminated protein, is almost the same as that in lethal activity and Limulus gelation activity, which are caused entirely by lipid A, not by protein.

The difference between the chemical structure of the lipid A of $P$. gingivalis and that of enterobacteria was in the substitution of the phosphate group at position $4^{\prime}$ of nonreducing glucosamine and the type of fatty acids and their binding sites. The lipid A of $P$. gingivalis consists of unique branched fatty acids with longer carbon-atom chains than those of S. minnesota and other enterobacteria, as is shown in Fig. 1. The accumulated data on the relationship between the chemical structure and biological activity of lipid A obtained by using natural and chemically synthesized lipid A preparations suggest that both of these components, phosphate and fatty acids, play a crucial role in the endotoxic activity of lipid A (Galanos et al., 1984; Homma et al., 1985 ; Kanegasaki et al., 1984, 1986; Tanamoto et al., 1984a, b; Tanamoto, 1994a). Thus, the reason for the low endotoxicity of the $P$. gingivalis lipid A is thought to be the unique fatty acid components and the partial defect in the phosphate group. In fact, Bacteroides fragilis lipid A, which chemically resembles that of $P$. gingivalis, was found to express low or no endotoxic activity (Weintraub et al., 1989). However, the lipid A and, particularly, the LPS of $P$. gingivalis unexpectedly showed strong activity, even stronger than that of enterobacterial LPS with regard to the minimum stimulatory dose, in induction of TNF in the human pro-monomyelocytic cell line THP-1. These results indicate that the chemical structure of the lipid A needed for the manifestation of endotoxic activity differs 
in humans and mice. Alternatively the difference suggests that a different pathway may exist in the recognition mechanism of LPS including that for the receptor. A difference in behaviour of some lipid A analogues toward human and murine macrophages has also been reported, i.e. a lipid A precursor (lipid IV $\mathrm{IV}_{\mathrm{A}}$ or $406)$ is an agonist in murine cells and exhibits strong lethality for mice (Galanos et al., 1984; Kanegasaki et al., 1984; Tanamoto, 1994b), while it expresses no endotoxicity in human cells and antagonizes LPS action (Golenbock et al., 1991; Kovach et al., 1990; Loppnow et al., 1989). Recently the signal transducing pathway of LPS in macrophages has become well, but not completely, understood. The activation in both human and mouse cells is thought to occur by the mediation of LBP and CD14 (Tobias et al., 1993; Wright et al., 1990). However, the possibility still remains that there are molecules on the cells which directly accept the LPS molecule and transduce a signal which is independent of the serum factor and therefore CD14 (Kitchens \& Munford, 1995; Nishijima et al., 1994; Weinstein et al., 1993). Although we still do not know what difference there is in the stimulation pathway in humans and mice, there may be a special point which discriminates the response of human and murine cells, and regulates the sensitivity depending on the chemical structure of the lipid A. The strong sensitivity of human cells to $P$. gingivalis LPS has also been found in human gingival fibroblasts for the induction of inflammatory mediators such as interleukin-1, -6 and -8 (Takada et al., 1991; Tamura et al., 1992; Yamaji et al., 1995). The fact that the lipid A, as well as LPS, of $P$. gingivalis is a potent stimulator in human cells suggests that it may play a more important role as a pathogenic factor in periodontopathic diseases than is expected from the findings of its low endotoxicity in mice.

Another novel action of the $P$. gingivalis LPS is the stimulation of the LPS non-responsive mouse strain $\mathrm{C} 3 \mathrm{H} / \mathrm{HeJ}$ to induce splenocyte mitogenicity (Joiner et al., 1982; Koga et al., 1985). It is of great interest whether the free lipid A of $P$. gingivalis is an activator in the mouse. However the stimulation by lipid A of LPS non-responsive mice was not as strong as that of LPS responsive mice and therefore we cannot ignore the possible activity of contaminating protein in this case. Since our preparation still contains a small amount of protein, which may cause stimulation of the LPS nonresponsive mouse, we cannot determine whether the lipid A part of the unique chemical structure is really responsible for the activity. We are trying to clarify this by using several strategies, including the chemical synthesis of the complete and partial structure of lipid A determined by us.

\section{ACKNOWLEDGEMENTS}

The skilful technical assistance of T. Iida is greatly appreciated. This work was supported by grants from the Ministry of Education, Science and Culture (06670313 to K. T., 06771618 to Y.H., 04671111 to H.K. and 06670313 to T.U.).

\section{REFERENCES}

Birkedal-Hansen, H., Taylor, R. E., Zambon, J. J., Barwa, P. K. \& Neiders, M. E. (1988). Characterization of collagenolytic activity from strains of Bacteroides gingivalis. J Periodont Res 23, 258-264.

Brondz, I., Calsson, J., Sjostrom, M. \& Sundqvist, G. (1989). Significance of cellular fatty acids and sugars in defining the genus Porphyromonas. Int J Syst Bacteriol 39, 314-318.

Fujimara, S. \& Nakamura, T. (1987). Isolation and characterization of a protease from Bacteroides gingivalis. Infect Immun 55, 716-720.

Fujiwara, T., Ogawa, T., Sobue, S. \& Hamada, S. (1990). Chemical, immunobiological and antigenic characterizations of lipopolysaccharides from Bacteroides gingivalis strains. J Gen Microbiol 136, 319-326.

Galanos, C., Freudenberg, M. A. \& Reutter, W. (1979). Galactosamine-induced sensitization to the lethal effects of endotoxin. Proc Natl Acad Sci USA 76, 5939-5943.

Galanos, C., Lehmann, Y., Luderitz, O., Rietschel, E. T., Westphal, O., Brade, H., Brade, L., Freudenberg, M. A., Hansen-Hagge, T., Luderitz, T., McKenzie, G., Shade, U., Strittmatter, W., Tanamoto, K., Zăhringer, U., Imoto, M., Yoshimura, H., Yamamoto, M., Kusumoto, S. \& Shiba, T. (1984). Endotoxic properties of chemically synthesized lipid A part structures. Comparison of synthetic lipid A precursor and synthetic analogues with biosynthetic precursor and free lipid A. Eur J Biochem 140, 221-227.

Golenbock, D. T., Hampton, R. Y., Qureshi, N., Takayama, K. \& Raetz, C. R. H. (1991). Lipid A-like molecules that antagonize the effects of endotoxins on human monocytes. J Biol Chem 266, 19490-19498.

Green, L. C., Wanger, D. A., Glogowsky, J., Sipper, P. L., Wishnok, J. S. \& Tannenbaum, S. R. (1982). Analysis of nitrate, nitrite, and $\left[{ }^{15} \mathrm{~N}\right]$ nitrate in biological fluids. Anal Biochem 126, 131-138.

Hamada, S., Takada, H., Mihara, J., Nakagawa, I. \& Fujiwara, T. (1990). LPS of oral Bacteroides species: general properties and induction of cytokines in human gingival fibroblast cultures. In Cellular and Molecular Aspects of Endotoxin Reactions, pp. 285-294. Edited by A. Nowotny, J. J. Spitzer \& E. J. Ziegler. Amsterdam: Elsevier Science Publishers.

Homma, J. Y., Matsuura, M., Kanegasaki, S., Kawakubo, Y., Kojima, Y., Shibukawa, N., Kumazawa, Y., Yamamoto, A., Tanamoto, K., Yasuda, T., Imoto, M., Yoshimura, H., Kusomoto, S. \& Shiba, T. (1985). Structural requirements of lipid A responsible for the functions: a study with chemically synthesized lipid A and its analogues. $J$ Biochem 98, 395-406.

lino, Y. \& Hopes, R. M. (1984). The bone resorbing activities in tissue culture of lipopolysaccharides from the bacteria Actinobacillus actinomycetemcomitans, Bacteroides gingivalis, and Capnocytophaga ochracea isolated from human mouths. Arch Oral Biol 29, 59-63.

Joiner, K. A., McAdam, K. P. W. J. \& Kasper, D. L. (1982). Lipopolysaccharides from Bacteroides fragilis are mitogenic for spleen cells from endotoxin responder and nonresponder mice. Infect Immun 36, 1139-1145.

Johne, B., Olsen, I. \& Bryn, K. (1988). Fatty acids and sugars in lipopolysaccharides from Bacteroides intermedius, Bacteroides gingivalis and Bacteroides loescheii. Oral Microbiol Immunol 3, 22-27.

Kanegasaki, S., Kojima, Y., Matsuura, M., Homma, J. Y., Yamamoto, A., Kumazawa, Y., Tanamoto, K., Yasuda, T., Thujimoto, Y., Imoto, M., Yoshimura, H., Yamamoto, M., Kusumoto, S. \& Shiba, T. (1984). Biological activities of analogues 
of lipid A based on the revised structural model. Eur J Biochem 143, 237-242.

Kanegasaki, S., Tanamoto, K., Yasuda, T., Homma, J. Y., Matsuura, M., Nakatsuka, M., Kumazawa, Y., Yamamoto, A., Kumazawa, Y., Shiba, T., Kusumoto, S., Imoto, M., Yoshimura, H. \& Shimamoto, Y. (1986). Structure-activity relationship of lipid A: comparison of biological activities of natural and synthetic lipid A's with different fatty acid compositions. J Biochem 99, 1203-1210.

Kitchens, R. L. \& Munford, R. S. (1995). Enzymatically deacylated lipopolysaccharide (LPS) can antagonize LPS at multiple sites in the LPS recognition pathway. J Biol Chem 270, 9904-9910.

Kitchens, R. L., Ulevitch, T. J. \& Munford, R. S. (1992). Lipopolysaccharide (LPS) partial structures inhibit responses to LPS in a human macrophages cell line without inhibiting LPS uptake by a CD14-mediated pathway. $J$ Exp Med 176, 485-494.

Koga, T., Nishihara, T., Fujiwara, T., Nishizawa, T., Okahashi, N., Noguchi, T. \& Hamada, S. (1985). Biochemical and immunobiological properties of lipopolysaccharide (LPS) from Bacteroides gingivalis and comparison with LPS from Escherichia coli. Infect Immun 47, 638-647.

Kovach, N., Yee, E., Munford, R. S., Raetz, C. R. H. \& Harlan, J. M. (1990). Lipid IVa inhibits synthesis and release of tumour necrosis factor induced by lipopolysaccharide in human blood ex vivo. $J$ Exp Med 172, 77-84.

Kumada, H., Haishima, Y., Umemoto, T. \& Tanamoto, K. (1995). Structural study on the free lipid A isolated from lipopolysaccharide of Porphyromonas gingivalis. J Bacteriol 177, 2098-2106.

Loppnow, H., Brade, H., Dürbaum, I., Dinarello, C. A., Kusumoto, S., Rietschel, E. Th. \& Flad, H.-D. (1989). IL-1 induction-capacity of defined lipopolysaccharide partial structures. J Immunol 142, 3229-3238.

Nair, B. C., Mayberry, W. R., Dziak, R., Chen, P. B., Levine, M. J. \& Hausmann, E. (1983). Biological effects of a purified lipopolysaccharide from Bacteroides gingivalis. J Periodont Res 18, 40-49.

Nishijima, M., Hara-Kuge, S., Takasuka, N., Akagawa, K., Setouchi, M., Matsuura, K., Yamamoto, S. \& Akamatsu, Y. (1994). Identification of biochemical lesion, and characteristic response to lipopolysaccharide (LPS) of a cultured macrophage-like cell mutant with defective LPS-binding. J Biochem 116, 1082-1087.

Qureshi, N. \& Takayama, K. (1982). Purification and determination of nontoxic lipid A obtained from the lipopolysaccharide of Salmonella typhimurium. J Biol Chem 257, 11808-11815.

Qureshi, N., Mascagni, P., Ribi, E. \& Takayama, K. (1985). Monophosphoryl lipid A obtained from lipopolysaccharides of Salmonella minnesota R595. Purification and complete structure determination. J Biol Chem 260, 5271-5278.

Rietschel, E. T., Wollenweber, H.-W., Brade, H., Zăhringer, U., Lindner, B., Seydel, U., Bradaczek, H., Barnickel, G., Labischinski, H. \& Giesbrecht, P. (1984). Structure and conformation of the lipid A component of lipopolysaccharides. In Handbook of Endotoxin, vol. 1, pp. 187-220. Edited by R. A. Proctor. Amsterdam : Elsevier Science Publishers.

Rietschel, E. T., Brade, L., Schade, U., Seydel, U., Zähringer, U., Kusumoto, S. \& Brade, H. (1988). Bacterial endotoxins: properties and structure of biologically active domains. In Surface Structures of Microorganisms and their Interactions with the Mammalian Host, pp. 1-41. Edited by E. Schrinner, M. H. Richmond, G. Seibert \& U. Schwarz. Weinheim: VCH.

Schifferle, R. E., Reddy, M. S., Zambon, J. J., Genko, R. J. \& Levine,
M. J. (1989). Characterization of a polysaccharide antigen from Bacteroides gingivalis. J Immunol 143, 3035-3042.

Sisney-Durrant, H. J. \& Hopps, R. M. (1991). Effect of lipopolysaccharide from Porphyromonas gingivalis on prostaglandin-E2 and interleukin- $1 \beta$ release from rat periosteal and human gingival fibroblasts in vitro. Oral Microbiol Immunol 6, 378-380.

Slots, J. \& Genco, R. J. (1984). Microbial pathogenicity. Black pigmented Bacteroides species, Capnocytophaga species, and Actinobacillus actinomycetemcomitans in human periodontal disease: virulence factors in colonization, survival, and tissue destruction. J Dent Res 63, 412-421.

Slots, J. \& Gibbons, R. J. (1978). Attachment of Bacteroides melaninogenicus subsp. asaccharolyticus to oral surfaces and its possible role in colonization of the mouth and of periodontal pockets. Infect Immun 19, 254-264.

Takada, H., Hirai, H., Fujiwara, T., Koga, T. \& Hamada, S. (1990). Bacteroides lipopolysaccharides (LPS) induce anaphylactoid and lethal reactions in LPS-responsive and nonresponsive mice primed with muramyl dipeptide. J Infect Dis 162, 428-434.

Takada, H., Mihara, J., Morisaki, I. \& Hamada, S. (1991). Induction of interleukin-1 and -6 in human gingival fibroblast cultures stimulated with Bacteroides lipopolysaccharides. Infect Immun 59, 295-301.

Tamura, M., Tokuda, M., Nagaoka, S. \& Takada, H. (1992). Lipopolysaccharides of Bacteroides intermedius (Prevotella intermedius) and Bacteroides (Porphyromonas) gingivalis induce interleukin-8 gene expression in human gingival fibroblast cultures. Infect Immun 60, 4932-4937.

Tanamoto, K. (1994a). Free hydroxyl groups are not required for endotoxic activity of lipid A. Infect Immun 62, 1705-1709.

Tanamoto, K. (1994b). Bacterial pathogenesis; interaction of pathogenic bacteria with host cells. Methods Enzymol 236, 31-41.

Tanamoto, K., Galanos, C., Luderitz, O., Kusumoto, S. \& Shiba, T. (1984a). Mitogenic activities of synthetic lipid $A$ analogues and suppression of mitogenicity of lipid A. Infect Immun 44, 427-433.

Tanamoto, K., Zahringer, U., McKenzie, G., Galanos, C., Rietschel, E. T., Luderitz, O., Kusumoto, S. \& Shiba, T. (1984b). Biological activities of synthetic lipid A analogs: pyrogenicity, lethal toxicity, anticomplement activity and induction of Limulus amoebocyte lysate. Infect Immun 44, 421-426.

Tobias, P. S., Soldau, K., Kline, L., Lee, J.-D., Martin, T. P. \& Ulevitch, R. J. (1993). Cross-linking of lipopolysaccharide (LPS) to CD14 on THP-1 cells mediated by LPS-binding protein. $J$ Immunol 150, 3011-3021.

Weinstein, S. L., June, C. H. \& DeFrance, A. L. (1993). Lipopolysaccharide-induced protein tyrosine phosphorylation in human macrophages is mediated by CD14. J Immunol 151, 3829-3838.

Weintraub, A., Zăhringer, U., Wollenweber, H.-W., Seydel, U. \& Rietschel, E. T. (1989). Structural characterization of the lipid A component of Bacteroides fragilis strain NCTC 9343 lipopolysaccharide. Eur J Biochem 183, 425-431.

Westphal, O., Luderitz, O. \& Bister, F. (1952). Über die Extraktion von Bakterien mit Phenol/Wasser. Z Naturforsch 76, 148-155.

Wilson, M. (1993). Biological activities of lipopolysaccharide and endotoxin. In Biology of the Species Porphyromonas gingivalis, pp. 171-198. Edited by H. N. Haroun. Boca Raton, FL: CRC Press.

Winkelhoff, A. J., Carlee, A. W. \& Graaff, J. (1985). Bacteroides endodontalis and other black-pigmented Bacteroides species in odontogenic abscesses. Infect Immun 49, 494-497.

Winkelhoff, A. J., Steenbergen, T. J. M. \& Graaff, J. (1993). Occurrence and association with disease. In Biology of the Species 
Porphyromonas gingivalis, pp. 33-44. Edited by H. N. Haroun. Boca Raton, Florida: CRC Press.

Wright, S. D., Ramos, R. A., Tobias, P. S., Ulevitch, R. J. \& Mathison, J. C. (1990). CD14, a receptor for complexes of lipopolysaccharide (LPS) and LPS binding protein. Science 249, 1431-1433.

Yamaji, Y., Kubota, T., Sasaguri, K., Sato, S., Suzuki, Y., Kumada,

H. \& Umemoto, T. (1995). Inflammatory cytokine gene expression in human periodontal ligament fibroblasts stimulated with bacterial lipopolysaccharides. Infect Immun 63, 3576-3581.

Zambon, J. J., Reynolds, H. S. \& Slots, J. (1981). Black-pigmented Bacteroides spp. in the human oral cavity. Infect Immun 32, 198-203.

Received 24 June 1996; accepted 27 August 1996. 